\title{
Small innovation businesses attached to higher schools as new funding source of Russian higher education
}

\author{
Sazonov Sergei \\ Volgograd State Technical University \\ the city of Volgograd, Russia \\ sazonovsp@mail.ru \\ Kharlamova Ekaterina \\ Volgograd State Technical University \\ the city of Volgograd, Russia \\ sikaterina@mail.ru
}

\author{
Ezangina Irina \\ Volgograd State Technical University \\ the city of Volgograd, Russia \\ ezangirina@rambler.ru
}

\author{
Pridachuk Maxim \\ Volgograd Institute of Management - branch of the Russian \\ Academy of National Economy and Public Administration \\ under the President of the Russian Federation \\ the city of Volgograd, Russia \\ pridachuk@mail.ru
}

\begin{abstract}
Modern conditions of development of educational sphere actualize new, additional funding sources of higher professional education capable of reproduction. Under conditions of market economy, higher schools, on the one hand, have to increase efficiency of using budgetary funds, received from the state, and, on the other - to attract resources from extra budgetary sources. Small innovation businesses attached to higher schools can become one of such sources. The authors of the paper have conducted analysis of activity of small innovation businesses attached to higher schools in the context of the world tendencies of development; the activity of their establishment was studied by federal districts and entities of the Russian Federation. Mutual benefits of cooperation between the higher school and business in the framework of the research object were proven. The factors, influencing the development of business associations and partnerships attached to higher schools, a number of problems in their development were identified; in this connection, the ways of solution of these problems were justified. Special attention was paid to incubation and acceleration programmes of higher schools as a promising direction of practice activation of establishing small innovation businesses. A conclusion about the urgency of developing small innovation businesses attached to higher schools in the context of strategy realisation of Russia innovation development and of formation of a competitive ecosystem of the state was made.
\end{abstract}

Keywords - higher school, small innovation business, funding source, commercialisation of intellectual property, higher school competitiveness, business-incubator

\section{TOPICALITY OF ENTREPRENEURIAL ACTIVITY IN MODERN HIGHER SCHOOL}

The change of the mechanisms of funding and reduction of the budget appropriations for higher schools of Russia sets the task before them of searching alternative sources of gaining profit for implementing their activity [1].
In 2016, the volume of federal budget expenditures on higher education reduced approximately by $2.5 \%$ in comparison with 2015 and equaled 504 bn. roubles.

In the structure of the consolidated budget of RF (Russian Federation), the volume of expenditures in the field of higher education increases annually. If in 2010 budgetary expenditures were 377.8 bn. roubles, in 2015 and 2016 they increased almost by $40 \%$ and amounted to 519.7 and 514.64 bn. roubles, correspondingly. The following expenditures were provided for higher schools in 2016: in federal budget 514.64 bn. roubles (in 2010 - 364.5 bn. roubles; in $2013-$ 495.6 bn. roubles; in 2014 - 498.2 bn. roubles) and in consolidated budgets of the Russian Federation entities 20.66 bn. roubles (in $2010-13.3$ bn. roubles; in $2013-17$ bn. roubles; in $2014-21.6$ bn. roubles).

Expenditures of the consolidated budget of the Russian Federation on the education in dynamics are presented in Figure 1 [2].

Today, in educational foundations of higher schools, there is a lack of funding, but at that they possess advanced scientific developments, which can be successfully realised and raise income, that is, implement commercialisation.

To provide additional funding sources by means of commercialisation and practical application (introduction) of the results of intellectual activity (RIA) allows establishing small innovation entrepreneurship (SIE) attached to the higher school. 


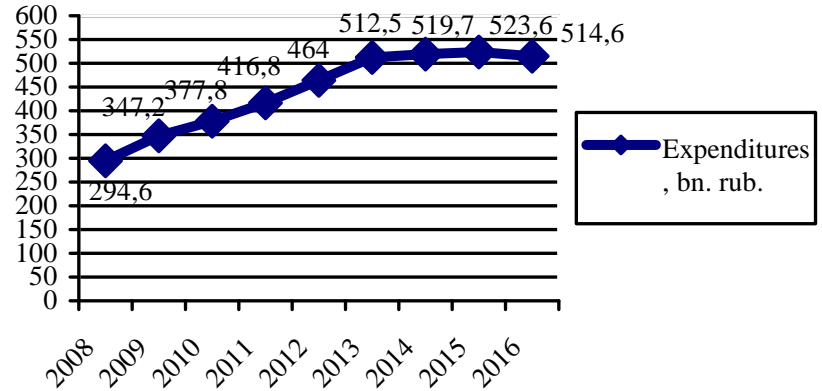

Fig. 1. Budget expenditures on higher education in Russia, bn. rub. [2]

At present, the most popular directions of SIE activity are: mechanical engineering, robotics, physics, chemistry, biotechnology, medicine and IT technology.

Federal law No. 217-FL of 02.08.2009 served as the incentive to SIE development, the purpose of which is provision of a possibility of practical application of the results of intellectual activity (RIA), established owing to the state funding at higher schools.

\section{SMALL INNOVATION BUSINESS: FACTORS OF DEVELOPMENT, RUSSIAN AND WORLD EXPERIENCE OF HIGHER SCHOOLS}

A small innovation business (SIB) implies a business association, the activity of which consists in practical application (introduction) of RIA (computer programmes, data bases, inventions, useful models, industrial samples, selection achievements, topographies of integrated circuits, know-how), the exclusive rights to which belong to the higher school. Similar companies can conjointly belong to higher schools, local municipalities, and regional authorities.

The concept "small innovative business" can be divided into two constituents: "innovation" and "small business". The peculiarity of small businesses is a possibility to develop innovation products, which are unprofitable and unattractive for large-scale enterprises [3].

Established SIB that are attached to higher schools serve as a result of the tried-and-true mechanism of transforming the developments into businesses, providing a complete production cycle and enabling a rise in the employment level, creation of new jobs in the scientific and technical field, an increase of the innovative product yield and its share in the total volume of shipped goods, jobs and services [4].

Actually small businesses attached to higher schools existed earlier (thus, for instance, at MSU, before implementing a new law, 85 such businesses were established), but higher schools did not have right to participate in formation of their authorized capital. Adoption of the above-mentioned law allowed higher schools to invest their own resources in establishing SIB [5].

Incomes gained from established business associations can be directed at the legal safeguard of the results of intellectual activity, payment of remuneration to their authors and at implementation of the main activity of institutions - at education and science [6].

The practice of commercialisation and entrepreneurship in educational organisations has been successfully developed abroad for a long time. Table 1 presents examples of establishing structures, aimed at commercialisation of scientific and research activity, which were established in the biggest research and education centres.

TABLE I. ORGANISATIONS ESTABLISHED WITH THE SUPPORT AND COLLABORATION OF OVERSEAS HIGHER SCHOOLS

\begin{tabular}{|c|c|c|c|}
\hline \begin{tabular}{l|} 
No. \\
item
\end{tabular} & $\begin{array}{c}\text { Name of overseas } \\
\text { research and } \\
\text { educational } \\
\text { centres }\end{array}$ & Country & $\begin{array}{l}\text { Special structures aimed at } \\
\text { commercialisation of results of } \\
\text { scientific and research activity }\end{array}$ \\
\hline 2 & Ohio University & USA & $\begin{array}{c}\text { Innovation Centre; Technology } \\
\text { Transfer Centre; }\end{array}$ \\
\hline 3 & $\begin{array}{l}\text { Stanford } \\
\text { University }\end{array}$ & USA & $\begin{array}{l}\text { Stanford programme of technological } \\
\text { enterprises (centre for executives and } \\
\text { owners of companies in Silicon Valley) }\end{array}$ \\
\hline 5 & $\begin{array}{c}\text { Technical Univers } \\
\text { ity of Munich }\end{array}$ & Germany & $\begin{array}{c}\text { Patent and Licensed Office (Munich); } \\
\text { Exchange of Knowledge Centre; } \\
\text { Entrepreneurship Centre; EU Relations } \\
\text { and Assistance in Research Funding } \\
\text { Department }\end{array}$ \\
\hline 6 & $\begin{array}{l}\text { Queensland } \\
\text { University }\end{array}$ & Australia & $\begin{array}{c}\text { Legal Department of research and } \\
\text { development of research activity based } \\
\text { on Queensland University }\end{array}$ \\
\hline 7 & $\begin{array}{l}\text { Waterloo } \\
\text { University }\end{array}$ & Canada & $\begin{array}{c}\text { (Contracts \& Industrial Grants section } \\
\text { of the Office of Research in Canada; } \\
\text { Research and Technology Park; } \\
\text { Intellectual Property Management } \\
\text { Group }\end{array}$ \\
\hline 9 & Beijing University & China & $\begin{array}{c}\text { Office of Technological Transfer and } \\
\text { Licensing; Three Scientific Parks in } \\
\text { Beijing area }\end{array}$ \\
\hline 10 & $\begin{array}{l}\text { National } \\
\text { University of } \\
\text { Singapore } \\
\end{array}$ & Singapore & $\begin{array}{c}\text { Entrepreneurship Development Centre; } \\
\begin{array}{c}\text { Business units (publishing houses, } \\
\text { technology holding company) }\end{array}\end{array}$ \\
\hline 11 & $\begin{array}{l}\text { King Fahd } \\
\text { University of } \\
\text { Petroleum \& } \\
\text { Minerals }\end{array}$ & $\begin{array}{l}\text { Saudi } \\
\text { Arabia }\end{array}$ & $\begin{array}{c}\text { Dhahran Techno-Valley; Research } \\
\text { Centre }\end{array}$ \\
\hline
\end{tabular}

One of the main purposes of establishing SIB attached to higher schools is practical application and introduction of the results of intellectual activity, exclusive rights to which belong to scientific institutions. Formation of SIB attached to higher schools is admitted as an important stage on the course of development and introduction of advanced technologies and act as a criterion of successfulness and high demand of the scientific activity of the higher school [7]. In addition, many authors see the purpose of establishing SIB in rendering assistance to students in adaptation to practical activity [8].

It is possible to indicate several factors that influence the development of SIB attached to higher education (Figure 2). 


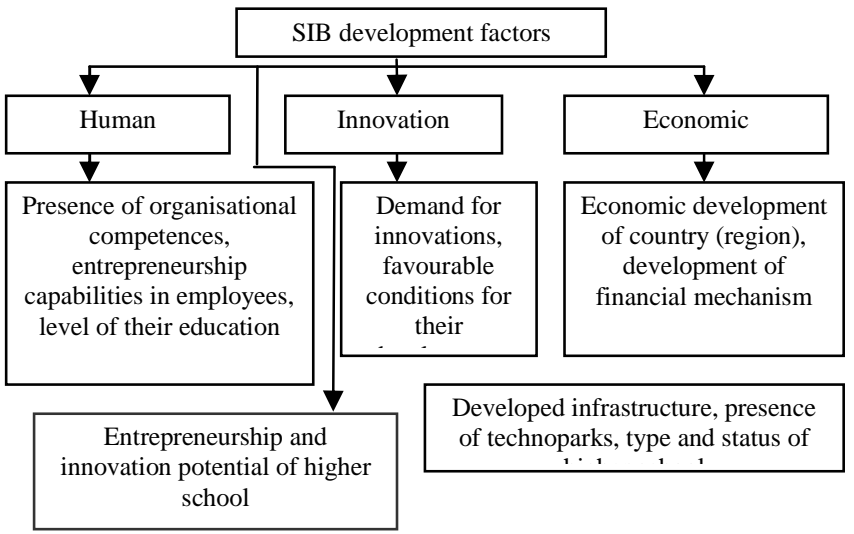

Fig. 2. Factors influencing the functioning of SIB attached to higher schools [9]

Collaboration of scientific centres and small innovation businesses allows establishing local scientific and production associations that continuously initiate scientific search, transforming ideas into technological innovations, testing new technologies and introducing them in production of scienceintensive import-substituting products.

At present, in Russia, since 2009, after adopting 217 FL (Federal Law), according to which higher schools are allowed to establish small innovation businesses affiliated to them, a large number of SIB has also been functioning. As of 01.06.2017, based on information of the portal of registering and monitoring SIB of scientific and educational field of the Ministry of Science and Education of RF, the information on 2645 acting business associations (BA) and business partnerships (BP) is logged in the official data base. Altogether, over the analysed period of 2009-2017, 2908 SIB (liquidation percent was 9.04\%) were established (Figure $3)$.

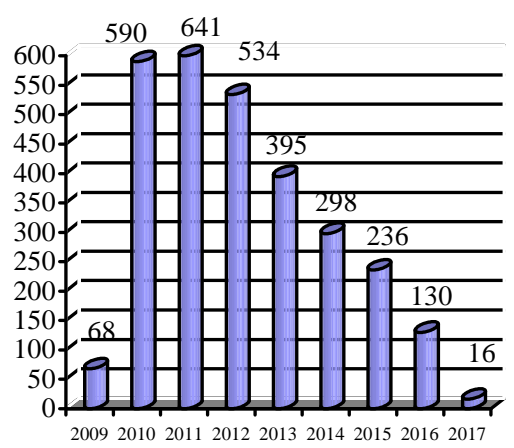

Number of SIB, units

$\begin{array}{lll}\square \text { South } & \square \text { Far Eastern } & \square \text { Privolzhskiy } \\ \square \text { North-Western } & \square \text { North-Caucasian } & \square \text { Siberian } \\ \square \text { Ural } & \square \text { Central }\end{array}$

Fig. 5. Russia's SIB distribution by federal districts as of 01.06.2017, \% [10]

Thus, in Tomsk region, 124 SIB (18 BA and BP per institution) fall to 7 entities of science and education (TSU, TPU, TSUAB, TSPU, TUSUR, Tomsk NRMU, FSBEI of HE of SibSMU of the Russian Ministry of Health) [10].

The experience on the support of SIB at National Research Tomsk Polytechnic University, where the functions of monitoring, analysis of the activity results, rendering
Analysis of statistical materials, generalised in Figure 4 showed that at present, higher schools of technical and technological profile, having a status of a research university, act as the leaders in SIB establishment. At the same time, BA and BP attached to humanitarian universities (including law and economics universities, as well as higher schools in the field of services, transport, government service, etc.), are being established.

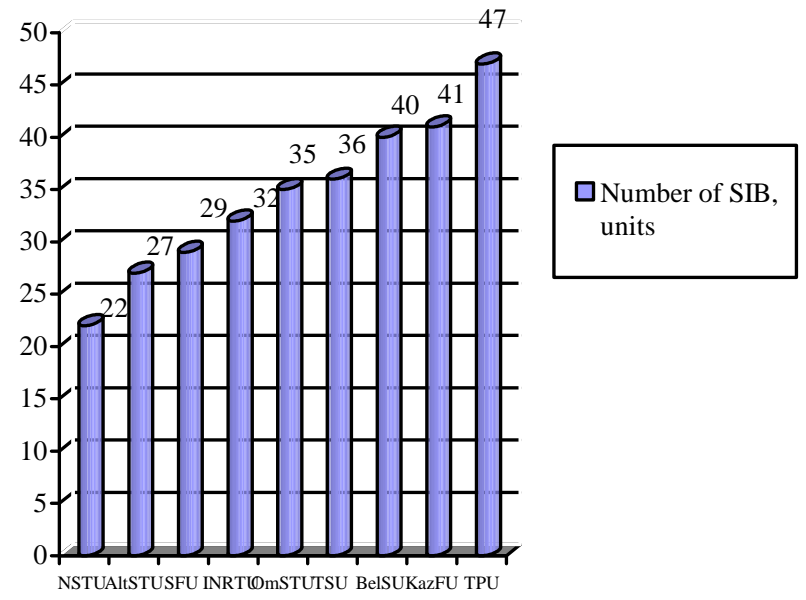

Fig. 4. Distribution of SIB by higher schools - founders as of 01.06.2017

The distribution pattern of SIB of Russia by federal districts (Figure 5) also proves the leadership of the university community of the Siberian Federal District, providing maximum concentration of innovation and business activity.

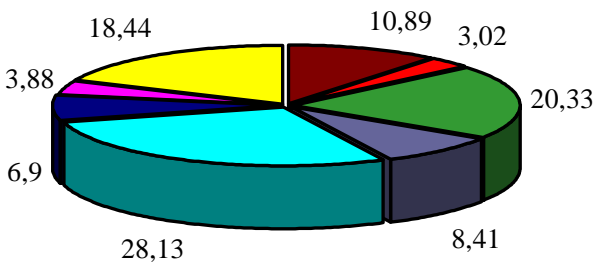

In the majority of cases, the founders were higher schoo me time, $3.8 \%$ of the established SIB were initiated scientific and research institutes of sectorial and departmental profile. 
assistance at stages of formation of businesses, formation of recommendations and consultations on conducting economic activity, accounting, taxation, traditions of business intercourse are assigned to a specialised organisational structure "Business-incubator", is notable.

\section{MUTUAL BENEFIT OF COLLABORATION BETWEEN HIGHER SCHOOL AND BUSINESS}

Despite a number of difficulties in establishment of SIB, higher schools have the following advantages that allow:

tracting additional source of higher school funding owing to the state support and commercialization of intellectual property;

- $\quad$ aising competitive capacity, rating, and image of the higher school;

- orming technoparks and business incubators;

- eveloping the material and technical base of the university; sharing equipment purchased by SIB or for them with the use of grant support, for scientific and educational purposes;

- $\quad$ reating jobs for doing practical work by students and job placement of the graduates.

Collaboration between the higher school and SIB can be called mutually beneficial since businesses, in turn, also gain a number of advantages as well:

- an opportunity of introduction and application of innovations;

- $\quad$ an opportunity of using preferential leasing without a tendering process;

- intake of highly-qualified specialists and young scientists in the staff;

- participation in the programmes of concessional financing and support on the part of the state, transition to the simplified tax system (STS);

Despite clear-cut advantages of SIB attached to higher schools, at present there are factors that constrain the establishment and functioning of such businesses.

\section{PROBLEMS ON THE PATH TO ESTABLISHING SMALL INNOVATION BUSINESSES ATTACHED TO HIGHER SCHOOLS}

The narrow focus of scientific studies of the higher school, its nonconformity with priority fields of science; weak innovation infrastructure of the higher school; absence of the experience in the marketing of innovations and practice of work in the open market; low activity of scientific staff at higher schools in establishing SIB; the insufficient initial internal financing of innovation activity; non-transparent statistics of activity efficiency of already functioning businesses, the founders of which were higher schools, served as essential factors constraining the establishment of SIB. A combination of the indicated factors mediates in turn low involvement of business, its associations, banking structures in financial support of innovation projects [11]. The principal funding source of development of innovation industrial enterprises is their own funds, which significantly limits the opportunities of their growth and development.

Besides, the practice is such that SIB of Russia can count on financial means provided in the framework of agreements on provision of grants of FSBI "Foundation of assistance in developing small forms of businesses in the scientific and technical field" (hereinafter called Foundation). Foundation's grant assistance of innovation projects, realised by SIB, implies stage-by-stage advancing the agreement, which objectively generates a necessity to monitor the efficiency of realisation of innovation projects, extension of agreements' terms, change of the work schedules. The procedure of drawing up and coordination of additional agreements takes time, as well as mediates formation of accounts payable on the SIB balance sheet, which frequently takes the form of overdue [12].

Considering a possibility of funding SIB in the context of priorities of development of venture business, one should emphasize an essential problem. In contrast to developed countries, where venture business serve the demands of largescale enterprises in advanced developments, the majority of Russian enterprises prefer to produce such developments independently without involving third-party organisations.

An alternative source of attracting venture financing is subject to review by regional institutes of development. As of 01.06.2017, 33 structures of this kind are functioning. Thus, on the territory of Volgograd region in the framework of the project of the Investment Development Agency, the Programme "Start-10" is realised, as well as the Regional venture foundation of investments in small-scale enterprises in the scientific and research field acts. The support of development of economic associations, provision of the increase of their shares (stacks) cost, subsequent sale of the latter, belonging to the foundation, for deriving the profit in the form of cash assets is declared as a purpose of investment in this project. In the priority of financing the Programme, there are 5 branches: information technology, software and telecommunication systems; medicine, pharmacology, biotechnology for medicine; chemistry, chemical technologies, new materials, construction; electronics, instrument-making, mechanical engineering; biotechnology, agriculture, food industry [13].

However, in essence, the majority of regional venture foundations are structures of support of innovation activity, aimed at funding research and development, and not implying establishment of new enterprises.

\section{PROSPECTIVE DIRECTIONS OF DEVELOPMENT}

In the context of the mentioned above, to reduce the factors, preventing from establishing SIB, and to establish favourable conditions for development in Russia, the implementation of the following measures is necessary:

- $\quad$ to change the legislative base, regulating activity of SIB attached to higher schools, taking into account their specifics and interests, simplifying the process of creation and strengthening the protection of intellectual 
property. Thus, simplification of the procedure of leasing premises attached to higher schools for SIB is significant;

- to strengthen the state support of SIB, including providing businesses with state demands;

- to render assistance in involvement of SIB in the process of regional clustering;

- $\quad$ to develop the system of support and incentives of SIB in the field of international projects;

- to establish a federal Internet resource for connecting gifted students, post-graduates, scientists with potential employers and investors;

- to include the efficiency indices of SIB activity in the indices (criteria) of higher school accrediting;

- to develop the centres of financial support of small-scale entrepreneurship in Russia, including those that are based on the existing state institutions of development. It is a question of the Foundation of promotion of smallscale businesses in the scientific and technical field (the Foundation of Bortnik), JSC "Russian venture company" (RVC), JSC "RUSNANO", Innovation Centre "Skolkovo". A certain productive experience in this direction has been accumulated. Thus, since 2010, the conditions and channels for transferring knowledge and technologies have been established among Research Institutes of the Russian Academy of Sciences (RAS), JSC "RUSNANO", LLC "Infrafond RVK" and a business in the field of nanotechnologies. It is a question of the Technology Transfer Centre (TTC) of RAS and RUSNANO, of Technological business-incubator of RAS. There are 55 investment decisions in the list of TTC projects, the implementation of which is accompanied by business organisation (SIB). One should note the variety of technological directions of the latter: nanosystem industry, biomed, instrumentmaking, energotech, nucleartech, telecom, new materials, catalysts

(Figure

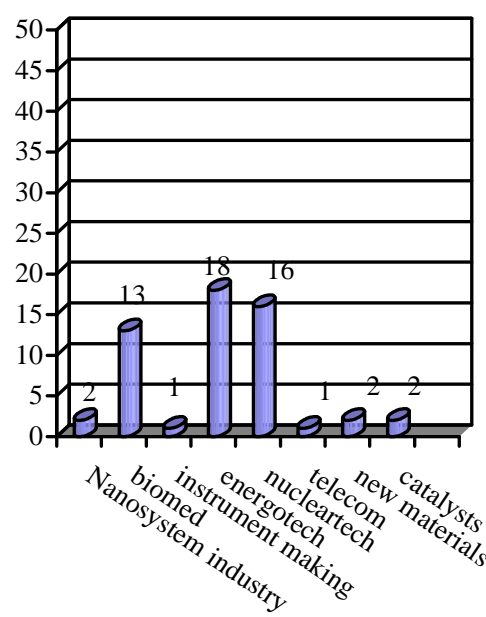

Number of SIB units

Fig. 6. Technological directions of TTC projects [14]

The established structure of the Technological BusinessIncubator of RAS is aimed at reproduction of leading-edge technologies in the field of materials science. At that, the residents of the business-incubator are rendered services in expertise of the project, development of business-plan, legal support, team-building, promotion in the market, attraction of further financing, etc. The established partnership relations of the team of "Technological Business-Incubator" with research institutes of RAS allowed forming a qualitative stream of projects on continuing basis.

\section{SMALL INNOVATION BUSINESSES IN THE SYSTEM OF BUSINESS-INCUBATORS OF HIGHER SCHOOLS}

At last, the significance of strengthening the participation of SIB in incubation and acceleration programmes of modern higher schools, which, according to the analytical report of UBI GLOBAL with the support of RVC and the businessincubator of NRU of HSB in Russia, number at present 72 units in 42 regions of the country, is objective. It is important to note that the average age of university programmes is only 4 years, whereas a similar index of the Russian programmes not connected with universities amounts to 8 years. The average annual operational budget by the Russian sample is a bit more than 265000 dollars, whereas by the global sample almost two times more (550000 dollars).

The TOP best Russian incubators and accelerators connected with universities include the following structures: Business-incubator ITMO (Saint Petersburg); Businessincubator IrNRTU (Irkutsk); Interuniversity Student Businessincubator "Druzhba", TUSUR (Tomsk); Captains of Russia (Russian Economic University named after G.V. Plekhanov, Moscow); iDealMachine (ITMO University, Saint Petersburg); Accelerator UrFU (Yekaterinburg). Frequently a community of higher schools act as initiators of business incubators and accelerators: Business-incubators "Ingriya" (Saint Petersburg); "LIFT" (Astrakhan); the First urban business-incubator (Saint Petersburg, 14 higher schools); Technopark "STROGINO" (Moscow); GVAccelarator 
(Moscow); NUMA Moscow (Moscow), Pulsar Venture Capital (Moscow).

The specialization of $34 \%$ studied incubators and accelerators is related to information and communication technology. A similar specialisation belong to $39 \%$ European and $48 \%$ global similar companies. A negative tendency consists in the fact that $17 \%$ of the studied programmes claimed about readiness to support any startup, but only $2 \%$ of programmes pay special attention to a sector of environmentally appropriate technologies.

The sources of financing business-models of higher school incubators and accelerators in Russia, in European and in the world practice are reflected in Figure 7.

At that, the statistic is such that over the last five years, business-incubators of higher schools and their residents attracted significantly less investments $(5.1 \mathrm{mln}$. dollars) than European (27 mln. dollars) and global (23 mln. dollars) ones did.

The investments from venture foundations, businessangels, corporations, the state, etc. were taken into account. On the one hand, the evidence of high demand for businessincubators to start a business serves the average number of filed annual applications (inquiries about participation in the programme) by Russian programmes (181 applications), which exceeds the corresponding indicator of similar European (153) and global (145) companies.

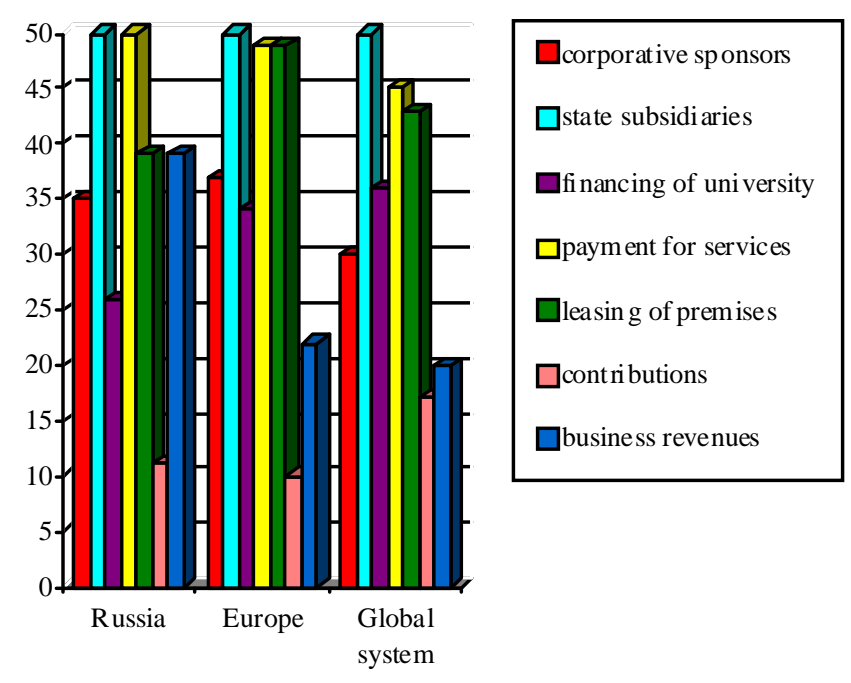

Fig. 7. Sources of the financing of business-models of higher schools' incubators and accelerators, mln. dollars [15]

The majority of residents of Russian incubators and accelerators begin to gain profit within 5 years from the moment of release $(27 \%)$, which exceeds a similar European indicator $(19 \%)$. But, at the same time interval, $22 \%$ startupgraduates cease their work in Russia (in Europe - $17 \%$ ) [15].

Understanding the significance of this element of the modern innovation system, the higher school community of the region with the support of the corresponding branch of power must contribute significant efforts to support the relations with other incubation and acceleration programmes, branch associations, communities of investors and corporate sponsors, forming a mechanism of specific innovation culture.

The work experience of Russian business-incubators and accelerators attached to modern domestic higher-schools showed that innovation programmes, despite significant differences in the number of residents and their sectorial belonging, staff, resources, and budgets, contribute to emergence of new generations of young entrepreneurs in the framework of SIB.

Thus, establishment of SIB acts as an important instrument of innovation development of Russia based on the use of scientific potential of modern higher schools and aimed at interconnection and permanent interaction with business. Under conditions of the limited state financing for higher schools, SIB means a prospective source of extra budgetary funds by means of creation and realisation of intellectual property at the expense of selling licenses and a financial mechanism of royalty.

\section{References}

[1] S.P. Sazonov, E.E. Kharlamova, I.A. Chekhovskaya, E.A. Polyanskaya, Mechanism of determination of effectiveness of spending assets of endowment funds on the basis of mathematical models, International Journal of Educational Management, Vol. 31, Issue 1, pp. 21-29, 2017.

[2] Data of official website of Ministry of Education and Science of Russian Federation http://fin.edu.ru/InfoPanel/min_obr1.html

[3] E.Yu. Legchilina, A.S. Platonova, Development of innovation small businesses attached to higher schools for commercialisation of intellectual activity, Omsk Scientific Herald, No. 1 (105), pp. 52-54. , 2012

[4] V.I. Petrishche, Directions of support of activity of small innovation busineses attached to higher schools at regional level, Herald of TISBI, No. 2 (54), pp. 92-99, 2013.

[5] M.M. Badaev, S.Yu. Aleksandrova, Problems and prospects of development of small innovation businesses attached to higher schools in Russian Federation, Carrying trade of Russia, No. 4, pp. 5-7, 2011.

[6] A.V. Ryadchikova, A.I. Leonidova, Small and medium-sized businesses attached to higher schools and RI: existing problems and ways of their solution, Actual problems of aviation and cosmonautics, Vol. 2. No. 8, pp. 397-398, 2012.

[7] M.A. Lebedev, Prospects of development of small innovation businesses attached to regional higher schools of Russia, Problems of modern economy (Novosibirsk),No. 11, pp. 80-84, 2013.

[8] T.R. Meshcheryakova, Peculiarities of establishing small innovation businesses attached to higher schools, Herald of Ural Institute of economics, management and law, No. 4 (21), pp. 38-42, 2012.

[9] S.V. Kovrigina, Review of modern sociological studies of small innovation businesses attached to higher schools and RI, Scientific studies and development of young scientists, No. 2, pp. 179-182, 2014.

[10] Registration and monitoring of small innovation businesses of scientific and educational field. Retrieved from: https://mip.extech.ru

[11] I.A. Ezangina, A.V. Evstratov, T.G. Yovanovich, Challenges and Perspectives for Development of Banking Credit Infrastructure in Russia , International Journal of Economics and Financial Issues, 2016, Vol. 6, No. 2S (Special Issue), pp. 58-64, Access mode: http://www.econjournals.com/index.php/ijefi/article/view/2532/pdf.

[12] Report on results of activity of FSBEI "Foundation of promotion of small forms of businesses in scientific and technical field" for 2016. Retrieved from: http://www.fasie.ru/upload/docs/2017-0324\%20Отчет\%203а\%202016\%20год.pdf

[13] Investment development agency of Volgograd region. Retrieved from: http://www.airvo.ru/innovation/finance/1/211

[14] Joint centre of technology transfer of RAS and RUSNANO. Retrieved from: http://ttorr.ru/rusnano_and_co_investors/projects_in_the_ttc/ 
[15] National comparative analysis 16/17 (Performance evaluation of Russian business incubators and accelerators). Retrieved from: http://www.rvc.ru/upload/iblock/4b1/UBI_Global-Russia-
Impact_Assessment_University-

Linked_Business_Incubators_Accelerators_RU.pdf 